\title{
Analysing Students' Learning Style to Predict the Most Important Factors that Affects the Performance of e-Learning Platform for Iraqi Postgraduate Studies using MLP-ANN Algorithm and Electronic Questionnaire
}

\author{
Nazhat Saed Abdul-Razak ${ }^{1}$, Maryam Abdul-Salam Ali ${ }^{2}$ \\ Assistant Professor Dr, Electro-Mechanical Engineering Department, University of Technology, Baghdad, Iraq ${ }^{1}$
}

Researcher, Computer Science Department, Iraqi Informatics Institute of Higher Education Studies, Baghdad, Iraq ${ }^{2}$

\begin{abstract}
The institutions of higher education now consider a key aspect in the development of educational reality in Iraq, and the focus of Iraqi universities and higher education institutions is nowadays, directed to enhance the learning environment for better learning opportunity of their students. With the information and communication technology era, we have a greater chance to make a whole new learning generation by creating intelligent electronic learning platforms that have a great impact on advancing students' educational level. In this research, we use one of the most well-known yet important artificial intelligence methods; one of them is called Educational Data Mining (EDM). That will be directed to extract hidden knowledge based on a pre-determined dataset from each student's learning behaviour inside a proposed electronic learning platform which is designed especially for higher education studies, the Department of Computer Science. Data repository contains all students' information. For example, age, country, university, previous occupation, and their grades obtained during the course, their learning behaviour, what course they choose, how many times did they re-take the exam until they pass, how many of them complete the course and how many of them have the course drooped. All these data are extracted after the proposed platform has been launched to a public website and used by actual students of higher education studies, then their learning data are kept in electronic learning repository to be used later to discover the most influencing factors about their learning process. For that purpose, two main questionaries' have been taken place, first one is taken prior the platform launching, and the second one taken after the platform launching and using by the students, the audience of the questionnaire were 100 students and faculty members in the institution of higher education, after the learning data have been accumulated, we use Multi Layer Perceptron (MLP) algorithm to evaluate the proposed e-learning platform performance to predict the most influencing factors in evaluating the proposed e-learning platform.
\end{abstract}

Keywords: Higher Education, Information Technology, Artificial Intelligence, Educational Data Mining (EDM), ELearning Platform, Learning Behaviour, Multilayer Perceptron Algorithm (MLP)

\section{INTRODUCTION}

Thanks to the information and communication technology era, our lives have been taken to another advanced level, the technology has affected each and every perspective of our society, and one of the most important perspectives that worth's our attention is the field of education. Countries progress has always been measured by the extent to which their students learn. That's why many Iraqi institutions have begun to keep abreast with the modern technology and for that reason many electronic learning platforms are designed, but unfortunately these platforms only serves to produce the scientific material electronically with some other features and nothing more. The usage of artificial intelligence in the field of e-learning is rare, and there is no actual observation of each student progress inside the platform, furthermore, there is no intelligent platform evaluation method taken place to evaluate the performance of the platforms. By making the student's is the core of the learning process the question of how to evaluate and develop these platforms is no longer restricted to faculty members and platform's supervisors. Based on a previous examination of student's results and achievements, it is possible to forecast a future plan to develop the existing e-learning platforms. And bases on the student's own opinion by taking a real questionnaire to obtain a feedback back about the proposed platform to make the student's is the main focus on the learning process we uses Educational Data mining (EDM), it's domain of interest is directed towards the educational dataset, it is usefulness is to produces an unknown knowledge from previously known dataset repository to create an intelligent knowledge representation process. This research mainly focuses on studying 


\section{International Advanced Research Journal in Science, Engineering and Technology}

Vol. 6, Issue 5, May 2019

the different indicators that affect the proposed e-learning platform by exploring student's enrolment data. The data repository is used to create an intelligent decision making and to extract hidden knowledge is taken from each student's data and behaviour inside the platform. This research offering an electronic platform for students of higher education that provides selective courses of the Department of Computer Science and through their behaviour in the platform and their grades in electronic tests we assess the effectiveness and efficiency of the proposed platform, and these data is used as an inputs to Multilayer Perceptron Algorithm (MLP) to predict the performance of the e-learning platform provided to the students by analysing the most significant factors affecting the development of the proposed e-learning platform through the behaviour of each student inside it. Section 2, concerning with relative previous studies. Section 3 , offers a general overview about data mining technique and MLP algorithm. Section 4, describes the proposed practical work. Section 5, discusses the extracted results and experiences. Section 6 offers a conclusion and the suggested future work.

\section{PREVIOUS STUDIES}

N. V. K. et al., 2017 proposed a new method to assess student achievement. A clustering data mining method is employed to investigate the extensive student dataset. A clustering technique will heighten the searching method pace and examination. The researchers found that assessing student achievement would improve the student occupations, and support the instructors and universities to use modern education systems or changes in the existing ones. V. Sarala et al., 2015 discuss the applications of data mining in educational institution to extract useful information from the huge data sets and providing analytical tool to view and use this information for decision making processes by taking real life examples. Jasvinder Kumar, 2015 Suggested a Comprehensive research by utilizing educational data mining technique supports to acquire and improve standards for the extension of the learning situation. It presents decision makers a bigger knowledge of student education and the background learning environment. Jai Ruby \& K. David, 2015 offered a comparable study form to predict the efficiency of the educational achievement of the students applying a Multi-Layer Perceptron method. The analysis confirmed that the characteristics distinguished in the research are effectively high influencing representatives in predicting learner achievement. This type of study is essentially concentrated on examining the prediction efficiency of the educational achievement of the learners applying only varying factors by using Multi-Layer Perceptron model and to match it with the prediction efficiency of the academic achievement of the learners by applying a dataset that includes of all educational, individual and financial attributes of the students. Jai Ruby \& K. David, 2014 Predicting the Achievement of learners in the Higher Education sector by utilizing data Mining Classification Algorithms using the learners information holding only the influencing factors and confirmed that multilayer perceptron algorithm (MLP), gives the best prediction. A.F.ElGamal, 2013 This study suggested an educational data mining pattern for predicting learner achievement especially in programming courses. The suggested pattern involves three stages; data pre-processing, selection of attributes and extraction of rules. Thilina Ranbaduge, 2013 shed the light on the application of various data mining methods in the educational data to recognize the extensive dataset on student education which can be employed to assess the student's overall achievements in the electronic learning environment upon systems and learn how these achievements are been managed to deliver out diverse education models of the learners. Annabel Latham et al., 2013 This study suggests a novel approach for profiling student learning methods for a conversational intelligent tutoring system (CITS) which employs a Multilayer Perceptron (MLP) algorithm. The record represents analyses carried with actual students in an active educational environment for profiling two dimensions Felder and Silverman styles. The decisions show that (MLP) can predict education techniques with an efficiency of $84-89 \%$.

T. Chellatamilan et al., 2011 aims to increase the education method evolving, learning content planning and learning objects suggestions based on the immediate data gathered within the e-learning platforms. For instance, Moodle. This paper applies the methods like data classification and clustering systems to predict the education style of the match learners based on their behaviours.

\section{DATA MINING (DM)}

In current years, the vast growth of artificial intelligence (AI) and deep learning presented different method for intelligent prediction and classification. Students' performance in an electronic learning platform is the main interest for educators and supervisors [10]. student's and platform's performance can be predicted through the use of data mining techniques or known as (DM), The definition of (DM) can be viewed as "the non-nugatory method of classifying valid, novel, previously unknown, potentially utilizable and understandable patterns from data in database. DM is generally have been used in commercial fields. Many researchers stated these days, there are a huge focus in applying the applications of data mining techniques in the education sectors [11].

There are several recognized (DM) algorithms classification like decision trees, Bayes nets, and MLP, which are applied to predict the achievements of the students [12]. The research is largely focus on how student's learning styles can affect the performance of the proposed e-learning platform. By extract a hidden knowledge behind the student's 


\title{
International Advanced Research Journal in Science, Engineering and Technology
}

\author{
Vol. 6, Issue 5, May 2019
}

education behaviours inside the platform to predict the performance of the system as well as to make an evaluation on how the prediction can be accurate in the field of Educational Data mining (EDM).

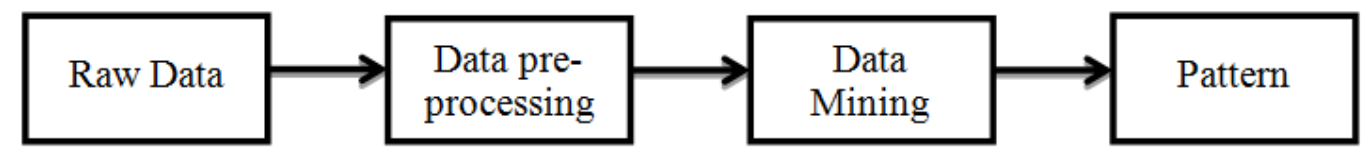

Fig. 1 Extracting patterns from data mining process [12]

\section{A. Educational Data Mining (EDM):}

EDM concerns with the utilizing of data mining algorithms in the educational fields to understand and overcome many obstacles in the educational sectors especially in an online-learning platforms, in order to develop and upgrade the quality of learning environments for both learners and faculty members [13]. Educational data mining technique (EDM) tries to convert raw data in knowledge discovery through data analysis and processing. EDM, involves 4 steps: data preparation, data mining and data analysis then data evaluation., this is a series of learning knowledge from data produced with an educational background and reusing it to enhance the educational environment.

\section{B. EDM Process}

Educational Data Mining is a growing discipline needs educational environments. For example, e-learning platforms that has capabilities and the needed methods to explore a raw dataset from the student's usage, in order to process these data to create a prediction and perform a better understanding of the learning patterns.

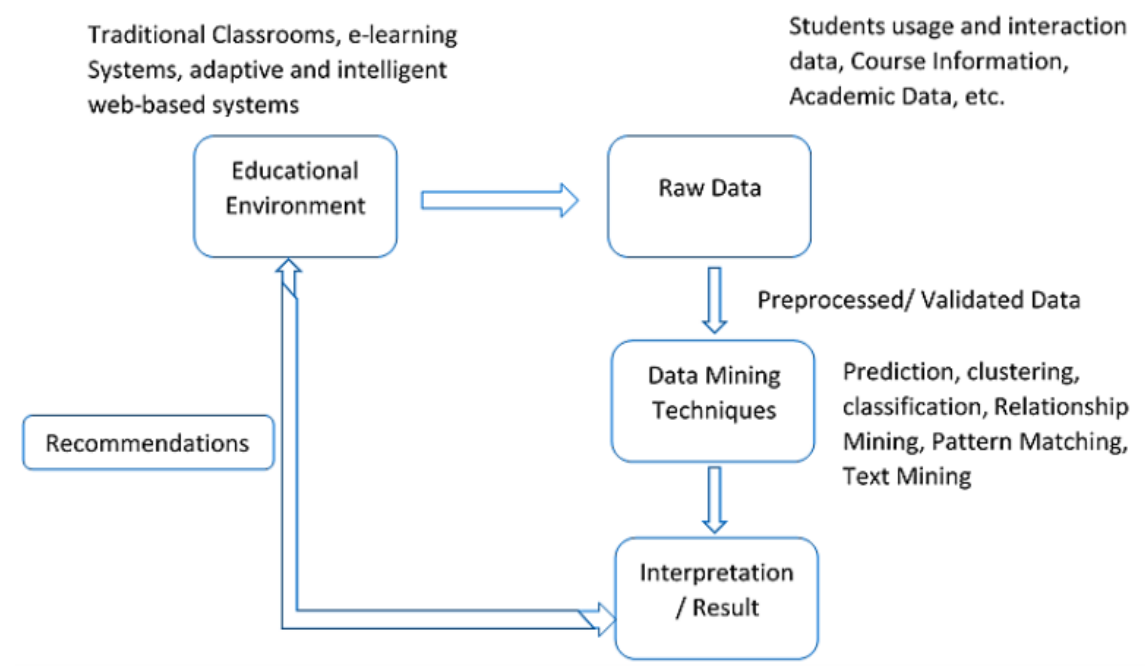

Fig. 2 EDM process [11]

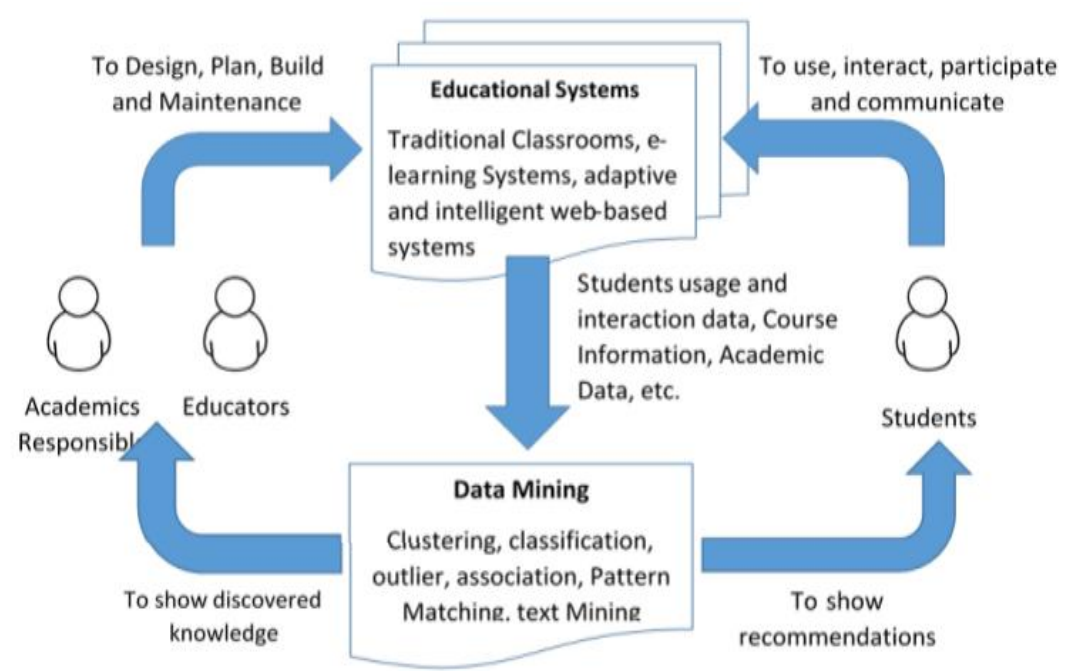

Fig. 3 Cycle of EDM process [11] 


\section{International Advanced Research Journal in Science, Engineering and Technology}

Vol. 6, Issue 5, May 2019

In order to create an educational data mining process we need three types of users 1- a students to interact with the proposed platforms, 2- an educator or supervisor to design and plan how the scientific materials can be delivered to the students through there platforms, 3-an educational environment to be used by both students and faculty members to exchange the academic courses.

\section{ARTIFICIAL NEURAL NETWORKS}

Artificial neural network techniques appeared as method employed in educational data mining (EDM). The power of ANN is that it is capable of finding all the similarities among set of different variables, the advantage of available computing power today has led to producing an extra layers of the neural network that can be employed, and deep learning interpretation can be effectively performed [10].The idea of artificial neural network has inspired by the biology of human brain model, human brain has a great inner computing nodes which referred to as neurons that can performed a complex processes. Therefore, ANNs can perform non-linear, highly complex interactions among set of inputs and outputs, also ANN have the ability to learn from a previous known data, so it can be easily trained by employing supervised learning model in order to create a classification from previously un-classified set of data [8]. ANN has a couple of basic elements named processing elements (neurons), and the associations among them (links). These links have special parameters associated with it these parameters refer to as (weights). The artificial network of neural has several layers (input layers, hidden layers, and output layers). Hidden layers are considered as the layers that can employ non-linear processing elements. Input values are forwarded through input layers to hidden layers to be processed when they are carried through the hidden layers to either another hidden layer or to the output layers.

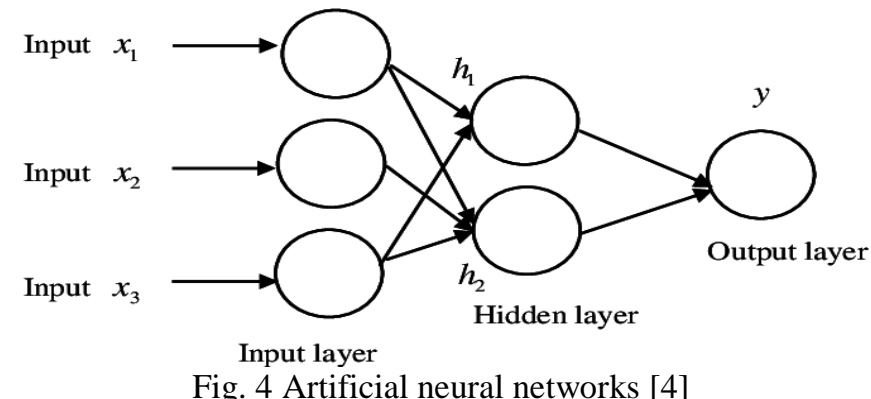

\section{MULTI-LAYER PERCEPTRON}

MLP - Multi-Layer Perceptron method considered as one of the most common extensively employed method in a general supervised learning artificial neural network algorithm. Multilayer Perceptron is a feed-forward artificial neural network model maps collections of input data in a number of satisfactory outputs. (MLP) has multiple layers of neurons where every layer is entirely related to the next one that can classify many data values in non-linear matter. These layers can learn how to map and direct input data values into a required form of responses. Therefore, they are largely employed for solving many classification and prediction problems [4]. MLP-ANNs have been strongly utilized in the prediction of breast cancer, students' academic performance, modelling student maintenance in science and engineering disciplines, and the prediction of student class choice in electronic higher education institutes [8].

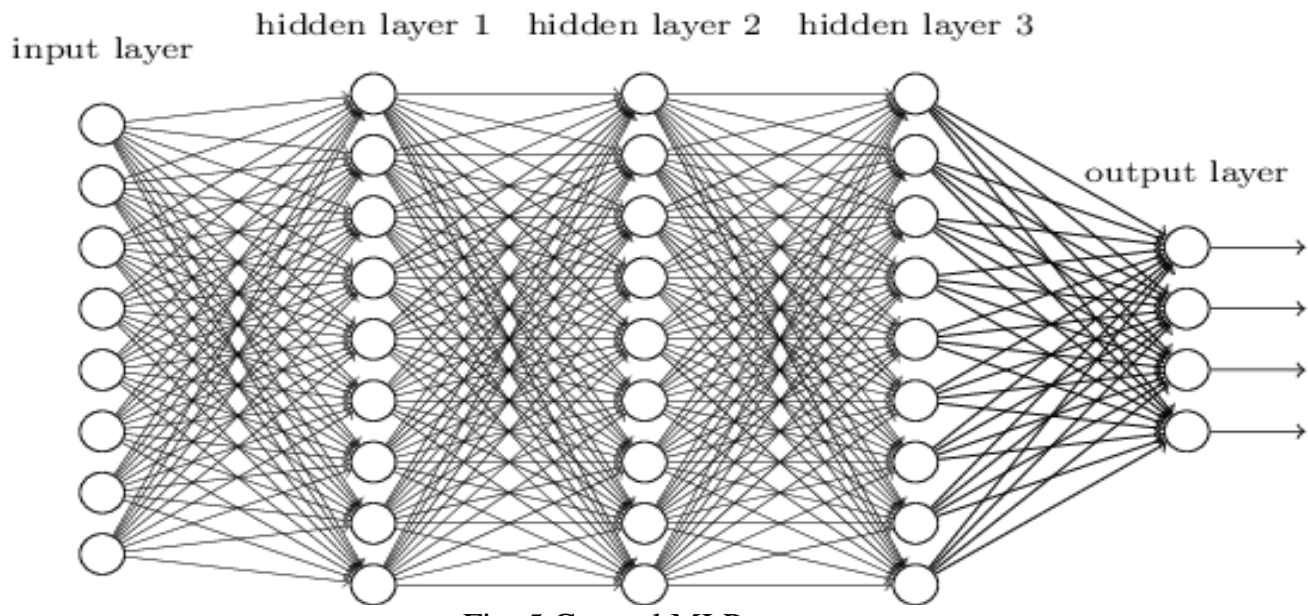

Fig. 5 General MLP structure 


\title{
International Advanced Research Journal in Science, Engineering and Technology
}

\author{
Vol. 6, Issue 5, May 2019
}

\section{RESEARCH METHODOLOGY}

In this paper, there are five main phases. First one is launching an electronic questionnaire to the students and faculty members of the higher education institutions to address the challenges that are facing the electronic learning development in Iraq. The second one, upon the results from the first questionnaire an intelligent electronic learning platform is designing and implementing to suit the student's needs and to overcome the obstacles facing their learning process. The third one, after launching the proposed platform to a public website and after it has been used by the students we are now able to collect the required data. The fourth one is taking another questionnaire; this one is taking place after 100 students have tried our proposed platform. The fifth one considers MLP algorithm to evaluate the overall performance of the proposed e-learning platform based on students' behaviour inside the platform and their grades, to extract knowledge about the most influencing factors on the overall evaluation for future development.

\section{A. First Phase}

Before launching the proposed platform to a public website, a prior questionnaire is carried out to both students and faculty members upon the challenges of implementing e-learning platform in the Iraqi universities so we can take the questionnaire results and try our best to overcome the disadvantage form the respective of both. We got three types of summaries as the following tables:

Table 1 Summary of Student's Questionnaire

\begin{tabular}{|l|l|l|l|}
\hline \multicolumn{1}{|c|}{ Question } & Agreed & Disagreed & \multicolumn{1}{|c|}{ Comment } \\
\hline $\begin{array}{l}\text { Does your department uses } \\
\text { electronic learning } \\
\text { platforms? }\end{array}$ & $46 \%$ & $54 \%$ & $\begin{array}{l}\text { We believe that it is essential that all university } \\
\text { departments must be able to provide e-learning } \\
\text { platforms to keep up with developed universities } \\
\text { around the world }\end{array}$ \\
\hline $\begin{array}{l}\text { Do you think that the use of } \\
\text { e-learning platforms is easy } \\
\text { or difficult? }\end{array}$ & $81 \%$ & $19 \%$ & $\begin{array}{l}\text { This depends on the student and on the breadth of } \\
\text { his/her knowledge of the e-learning platforms and } \\
\text { this result is considered good }\end{array}$ \\
\hline $\begin{array}{l}\text { Do you prefer a smartphone } \\
\text { or computer in the usage of } \\
\text { e-learning platforms? }\end{array}$ & $57 \%$ & $43 \%$ & $\begin{array}{l}\text { We suggest providing e-learning platforms suitable } \\
\text { for both smartphone and computers to provide the } \\
\text { flexibility of learning }\end{array}$ \\
\hline $\begin{array}{l}\text { Does your department } \\
\text { provide you free internet } \\
\text { access? }\end{array}$ & $12 \%$ & $88 \%$ & $\begin{array}{l}\text { This is disappointing result, because we live in a } \\
\text { world where the internet is dominating over all } \\
\text { aspects of life, and the students need to connect to } \\
\text { the Internet all the time to reach e-learning platforms } \\
\text { so they can share educational materials, ideas, take } \\
\text { courses, answer questions and make discussions. }\end{array}$ \\
\hline $\begin{array}{l}\text { Does your department } \\
\text { provide you modern } \\
\text { learning methods such as } \\
\text { smart board, data-show, and } \\
\text { others? }\end{array}$ & $45 \%$ & $55 \%$ & $\begin{array}{l}\text { The university has now started to introduce } \\
\text { intelligent teaching methods on the educational } \\
\text { process but at a slow pace. We believe that all } \\
\text { students have the right to learn in a smart and } \\
\text { modern way. }\end{array}$ \\
\hline
\end{tabular}

Table 2 Summary of Teachers Questionnaire

\begin{tabular}{|l|l|l|l|}
\hline Question & Agreed & Disagreed & \multicolumn{1}{|c|}{ Comment } \\
\hline $\begin{array}{l}\text { Does e-learning raise } \\
\text { students' educational level } \\
\text { and increase their success } \\
\text { rates? }\end{array}$ & $93 \%$ & $7 \%$ & $\begin{array}{l}\text { This is a very positive result that demonstrates the } \\
\text { awareness of the teaching staff of the importance of e- } \\
\text { learning in the advancement of the educational process } \\
\text { and pushes it towards the best and thus raises success } \\
\text { rates among the students. }\end{array}$ \\
\hline $\begin{array}{l}\text { Does e-learning help } \\
\text { students to adapt } \\
\text { themselves in the learning } \\
\text { process? }\end{array}$ & $96 \%$ & $4 \%$ & $\begin{array}{l}\text { This indicates the importance of e-learning and its } \\
\text { usefulness from the point of view of the teachers. We } \\
\text { must give sufficient confidence to our students. The } \\
\text { students have to rely on themselves also they can learn } \\
\text { how to discipline their time to learn. }\end{array}$ \\
\hline $\begin{array}{l}\text { Do e-learning platforms } \\
\text { provide facilities for }\end{array}$ & $81 \%$ & $19 \%$ & $\begin{array}{l}\text { This is a good result of the teachers' awareness about } \\
\text { the students with special needs or who lives in remote }\end{array}$ \\
\hline
\end{tabular}




\section{International Advanced Research Journal in Science, Engineering and Technology}

Vol. 6, Issue 5, May 2019

\begin{tabular}{|l|l|l|l|}
\hline $\begin{array}{l}\text { students with special } \\
\text { needs or students who } \\
\text { live in remote areas? }\end{array}$ & & $\begin{array}{l}\text { areas and how e-learning platforms will help them solve } \\
\text { their problems. }\end{array}$ \\
\hline $\begin{array}{l}\text { Does e-learning provide } \\
\text { ease of teaching staff in } \\
\text { pursuing } \\
\text { learning? }\end{array}$ & $95 \%$ & $5 \%$ & $\begin{array}{l}\text { Students vary in their cognitive abilities, but through e- } \\
\text { learning, they can repeat the course many times to } \\
\text { understand the lesson and ask their supervisor only in } \\
\text { situations that were difficult for them, therefore, teacher } \\
\text { is able to follow the progress of his students and only } \\
\text { targets the weakness points of their learning to strength } \\
\text { them. }\end{array}$ \\
\hline
\end{tabular}

Table 3 Summary of Questionnarie for Both Students and Teachers

\begin{tabular}{|c|c|c|c|}
\hline Question & Agreed & Disagreed & Comment \\
\hline $\begin{array}{l}\text { Do you consider e-learning } \\
\text { an effective way to learn? }\end{array}$ & $64 \%$ & $36 \%$ & $\begin{array}{l}\text { This is positive because it exceeds half the number } \\
\text { of respondents and indicates that of e-learning is an } \\
\text { effective way to learn according to them. }\end{array}$ \\
\hline $\begin{array}{l}\text { Do you prefer to use } \\
\text { traditional education or e- } \\
\text { learning methods? }\end{array}$ & $92 \%$ & $8 \%$ & $\begin{array}{l}\text { This percentage can be considered good thus its } \\
\text { relevance to the personal opinion of the responders. }\end{array}$ \\
\hline $\begin{array}{l}\text { Are you facing troubles } \\
\text { while using the e-learning } \\
\text { platforms? }\end{array}$ & $60 \%$ & $40 \%$ & $\begin{array}{l}\text { This is a promising result. But this does not mean } \\
\text { that we neglect the rest who suffer from difficulties } \\
\text { while using e-learning, so universities should take } \\
\text { care of this aspect and provide workshops on how } \\
\text { to use e-learning platforms. }\end{array}$ \\
\hline $\begin{array}{l}\text { Have you ever participated } \\
\text { in seminars or workshops } \\
\text { about e-learning? }\end{array}$ & $41 \%$ & $59 \%$ & $\begin{array}{l}\text { This result is disappointing because this indicates } \\
\text { negligence of spreading awareness of the } \\
\text { importance of e-learning by universities. We must } \\
\text { change this reality by conducting activities and } \\
\text { seminars on the importance of e-learning and } \\
\text { provide proper training for teaching staff and } \\
\text { students to guide them on the right path. }\end{array}$ \\
\hline $\begin{array}{l}\text { Do you consider Iraq is at a } \\
\text { late stage in the application } \\
\text { of e-learning? }\end{array}$ & $78 \%$ & $22 \%$ & $\begin{array}{l}\text { With the advent of the Internet, the impact of } \\
\text { development has come from our reality to keep our } \\
\text { country with pace of technological progress in the } \\
\text { rest of the world so e-learning must be } \\
\text { comprehensive and covers all the Iraqi universities. }\end{array}$ \\
\hline $\begin{array}{l}\text { How does the English } \\
\text { language affect the } \\
\text { understanding and use of e- } \\
\text { learning systems? }\end{array}$ & $88 \%$ & $12 \%$ & $\begin{array}{l}\text { English language is important to use e-learning } \\
\text { systems, so universities must provide free English } \\
\text { language courses to all of the student and faculty } \\
\text { member. }\end{array}$ \\
\hline $\begin{array}{l}\text { Do you think that the } \\
\text { Intellectual property rights } \\
\text { are important for the } \\
\text { application of e-learning in } \\
\text { Iraq? }\end{array}$ & $87 \%$ & $13 \%$ & $\begin{array}{l}\text { We find that there is a need to protect intellectual } \\
\text { rights and provide penalties against scientific theft. } \\
\text { Because of this, there is no room for creativity and } \\
\text { no incentive for innovation, therefore the protection } \\
\text { of intellectual rights is an urgent need. }\end{array}$ \\
\hline
\end{tabular}

\section{B. Second Phase}

This phase considers the design and implementation of the proposed e-learning platform. In order to know how the proposed platform is effective on the learning process on the post-graduate students, and to overcome the disadvantages that facing both the students and teachers from the questionnaire results. We design and implement an intelligent elearning platform for selective courses it is launched on public website known as electronic Iraqi college, and upon the results that we obtained from the questionnaire, we try to create perfect electronic learning environment that is suitable for both the students and teachers, and to cover all their needs and perspective on how the electronic platform should be. The following figure illustrates the steps of designing the platform: 


\section{International Advanced Research Journal in Science, Engineering and Technology}

Vol. 6, Issue 5, May 2019

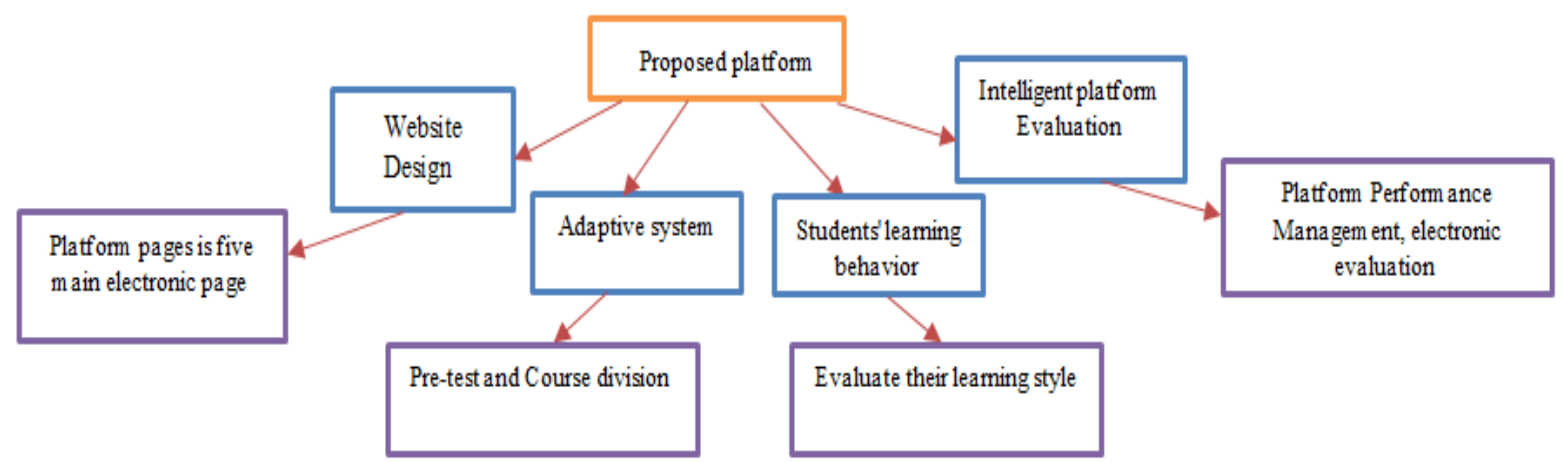

Fig. 6 General Structure of Platform Design

The platform is designed to have multi-level users. The guest page is available to everyone even if the visitor is neither a student nor a teacher, and this page contains general data about the platform and the institution of higher education. While students' pages appear only when each student enroll into the platform by creating a user account (from sign-up page) and then log-in to the platform to view all the courses and take all the exams related to the courses. This process is secured by encrypting the password of each student using a secure hashing algorithm (SHA-1). Upon the completion of the course by the student, an electronic certification is given to him/her as a reward of participation in the platform. Finally, there are the supervisors' pages that contain the results of intelligent automatic platform evaluation. The following figure shows the users level of the platform:

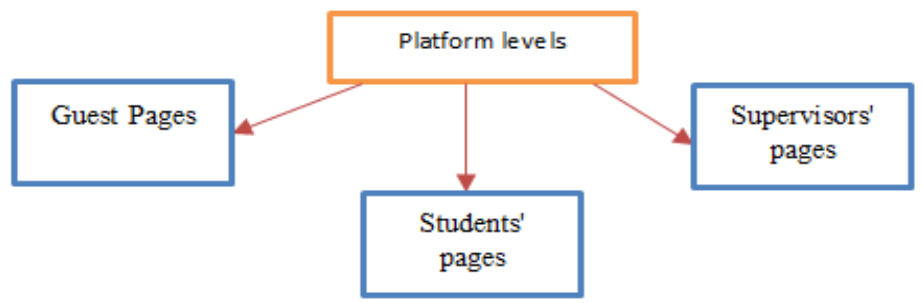

Fig. 7 Platform Users Levels

This platform contains six main courses according to the courses given in the Iraqi institution of higher education for the computer science department, level of M.Sc. and five additional pages that complete the learning process, each page is added as a column into the platform database and is available into each student profile. This table show details of platform pages like the following:

Table 4 Platform Main Pages

\begin{tabular}{|l|l|}
\hline Page & Details \\
\hline Courses & $\begin{array}{l}\text { Artificial intelligence, Advanced operating systems, Software engineering, } \\
\text { Databases, Data security, and Computer networks }\end{array}$ \\
\hline Electronic library & Contains electronic scientific books and works as a reference to the students \\
\hline $\begin{array}{l}\text { Electronic English } \\
\text { course }\end{array}$ & $\begin{array}{l}\text { TOFEL and/or IELTS course. We believe that learning English language is very } \\
\text { important especially in a scientific files such as the field of computer science }\end{array}$ \\
\hline Extra course & $\begin{array}{l}\text { Contains intensive scientific materials, for the students that faces difficulties in } \\
\text { passing the exams this course can help them }\end{array}$ \\
\hline Practice exam & $\begin{array}{l}\text { Contains additional quizzes and exams, so that the students can practice more on } \\
\text { how to answer the exam correctly }\end{array}$ \\
\hline
\end{tabular}

In order to observe and analyse the students' role inside the proposed platform, each page is programmed and used to connect the pages with the database, each attribute is given a pre-determined value, for example if the student pass the course the value inside the his pass or fail attribute become 1, otherwise it becomes 0 .

Table 5 Platform Users' Detailes

\begin{tabular}{|l|l|l|}
\hline \multicolumn{1}{|c|}{ Name } & \multicolumn{1}{c|}{ Type } & \multicolumn{1}{c|}{ Description } \\
\hline Student ID & Input attribute & Student's profile number \\
\hline First name & Input attribute & Student's first name \\
\hline Last name & Input attribute & Student's last name \\
\hline Mobile & Input attribute & Student's mobile number \\
\hline
\end{tabular}


IARJSET

International Advanced Research Journal in Science, Engineering and Technology

Vol. 6, Issue 5, May 2019

\begin{tabular}{|l|l|l|}
\hline E-mail & Input attribute & Student's or faculty e-mail \\
\hline Password & Input attribute & Student's encrypted password \\
\hline University & Input attribute & Student's university that uses this LMS \\
\hline Country & Input attribute & Student's country \\
\hline Pre-test & Input attribute & Pre-test score of 100/100 \\
\hline Level 1 quiz & Input attribute & Level one quiz score \\
\hline Level 2 mid-test & Input attribute & Level two middle test \\
\hline Level 2 final-test & Input attribute & Level three final test \\
\hline Final score & Input attribute & Final score of the fourth above scores \\
\hline Pass-fail & Input attribute & Either pass or fail the course \\
\hline Certification & Input attribute & Either took certification or not \\
\hline Open-library & Input attribute & Open platform library page \\
\hline Take-English-course & Input attribute & Take the English extra course \\
\hline Take-extra course & Input attribute & Type of extra course taken \\
\hline Take practice-course & Input attribute & Number practice sheets \\
\hline Number of levels passed & Input attribute & Number of passed levels \\
\hline System performance & Input attribute & System self-evaluation \\
\hline
\end{tabular}

Whenever a student signed in the platform, he/she is required to give certain data such as (Personal information, Contact information, and Account information including unique user name and password) the following flowchart shows the registration process:

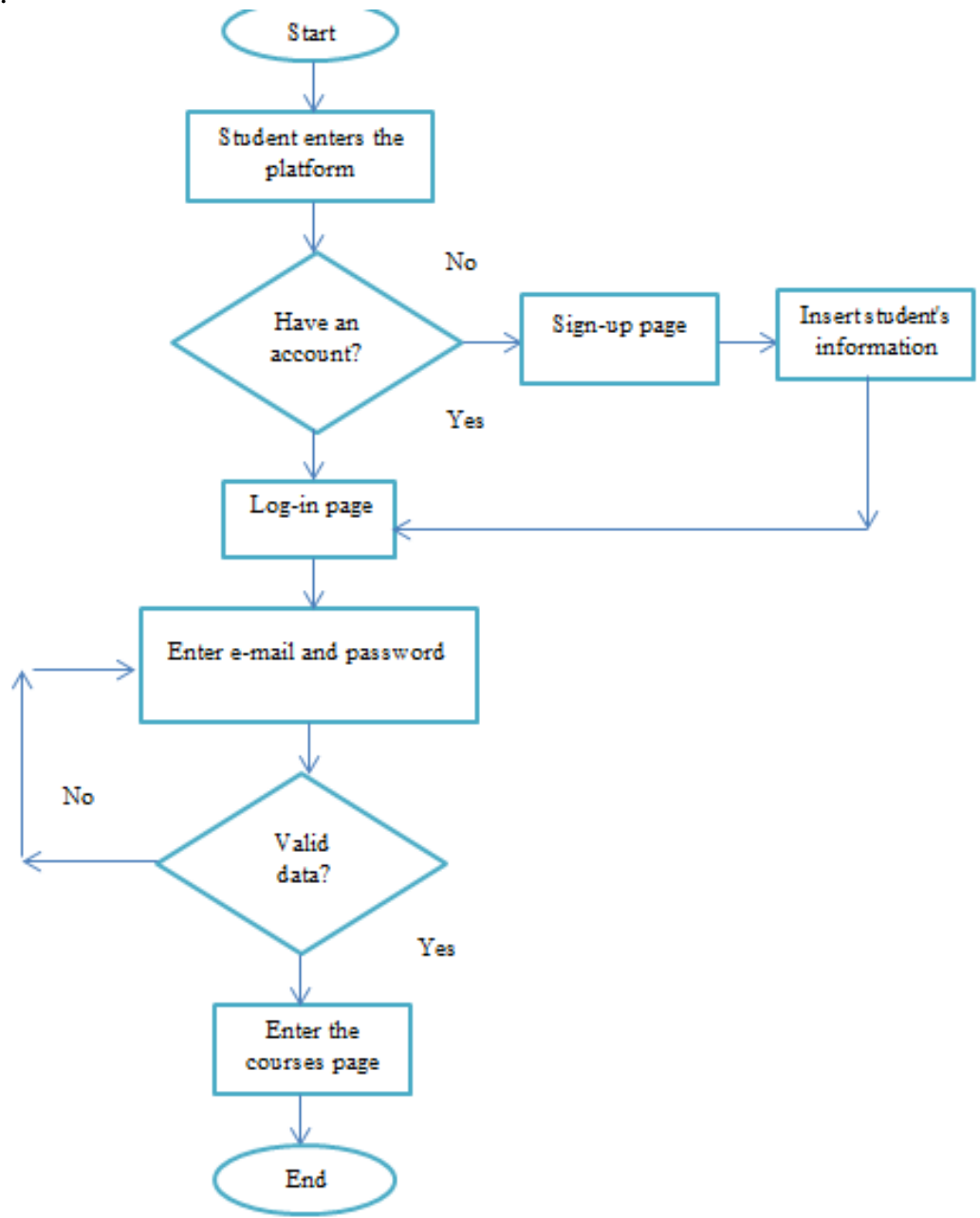

Flowchart 1 Student's Registration Process

To save the time and effort and to relief the burden of both student's and teacher, the platform courses is divided into three main sub-courses and a pre-test must be taken by each student who wishes to learn a certain course, upon the 


\section{International Advanced Research Journal in Science, Engineering and Technology}

Vol. 6, Issue 5, May 2019

grades of the student a suitable sub-course is shown to him/her. Proposed algorithm shows the division process of the course content (DCC) as the following:

\section{Algorithm 1 Divides the Course Contents}

Step 1: Input Student's pre-test score N, Other Data

Step 2: Get initial value from pre-test score $\mathrm{N}$

Step 3: The algorithm will process the score into three choices:

First choice: When the degree between 0-50 go to level 1

Second choice: When the degree large than 50 and less than 80 then go to level 2

Third choice: When the degree equal or large than 80 go to level 3

Step 4: Save the score of each student on his record

Now each student signed into the platform has a unique user profile inside the platform. The following figure shows the student profile:

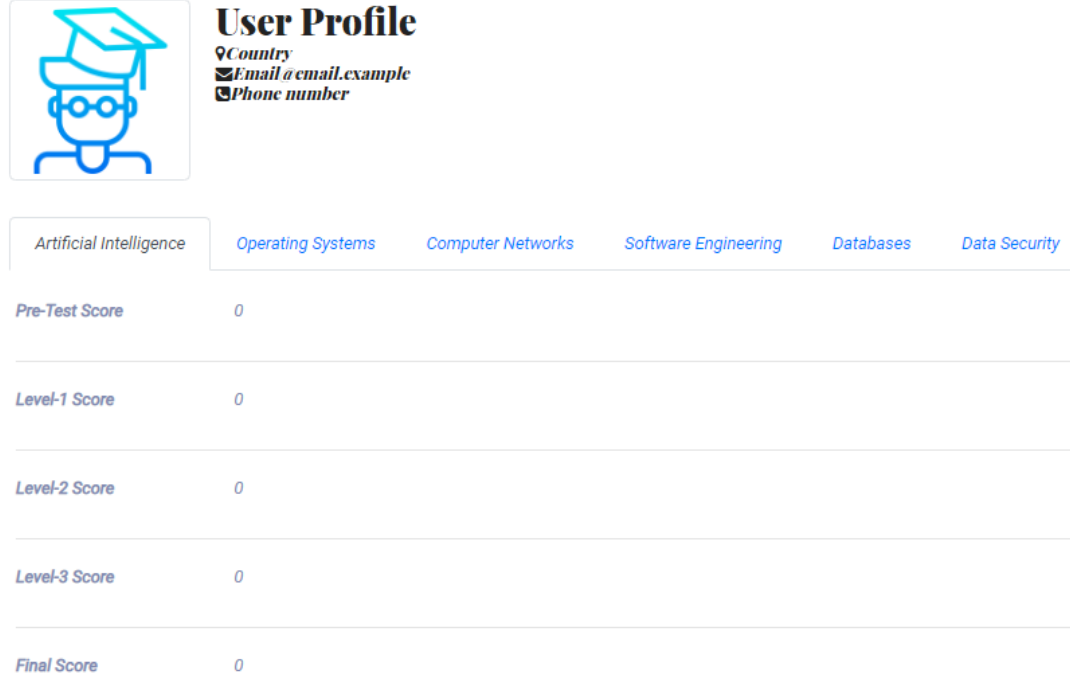

Fig. 8 User Profile

Also, the database that contains the entire student's data, these data are recorded inside the database in the form of binary fields ( 0 for negative action and 1 for positive action) and from there we can observe each student's behaviour. For example, how many times did the students take the exams, did he/she passes or not, is the extra pages were useful to the student's or not, how this platform helps the students in completing their required courses, etc. We have 100 volunteer that take the courses in our proposed platform, in order to observe the most influencing factors on the learning process of the students of higher education studies, then we accumulate their data and grades, and their behaviour inside the platform to create a learning dataset, then we combine with synthetic data in order to make the algorithm works better, and then we use MLP-ANN algorithm to predict the most influencing factors on the learning process of the students' of Iraqi higher education studies, and to make a prediction of who is going to pass all the courses, who will drop the course in the future based on a pre-defined data.

\section{Third Phase}

In this phase, a former questionnaire has been taken place, in order to observe the most influencing factors on the learning process from the opinion of the students who use our proposed platform, and then we use the proposed MLPANN algorithm in order to create a final conclusion on the results.

Table 7 Number of Times the Student has Re-Take the Tests

\begin{tabular}{|l|l|l|l|l|}
\hline \multicolumn{1}{|c|}{ Question } & $\begin{array}{l}\text { Passed from } \\
\text { first try }\end{array}$ & $\begin{array}{l}\text { Passed from } \\
\text { second try }\end{array}$ & $\begin{array}{l}\text { Passed from } \\
\text { third try }\end{array}$ & $\begin{array}{l}\text { Needed more } \\
\text { than three tries }\end{array}$ \\
\hline How many times did you take the pre-test? & $12 \%$ & $20 \%$ & $33 \%$ & $35 \%$ \\
\hline How many times Did you take level-1 Course? & $35 \%$ & $26 \%$ & $24 \%$ & $15 \%$ \\
\hline How many times Did you take level-2 course? & $21 \%$ & $43 \%$ & $22 \%$ & $14 \%$ \\
\hline How many times Did you take level-3 course? & $17 \%$ & $37 \%$ & $32 \%$ & $14 \%$ \\
\hline
\end{tabular}




\section{International Advanced Research Journal in Science, Engineering and Technology}

Vol. 6, Issue 5, May 2019

Table 8 Difficulty Ranges of the Exams

\begin{tabular}{|l|l|l|l|l|}
\hline Exam & Easy & Medium & Hard & Not sure \\
\hline pre-test & $36 \%$ & $18 \%$ & $29 \%$ & $17 \%$ \\
\hline level-1 course & $47 \%$ & $26 \%$ & $17 \%$ & $10 \%$ \\
\hline level-2 course & $31 \%$ & $28 \%$ & $21 \%$ & $20 \%$ \\
\hline level-3 course & $29 \%$ & $47 \%$ & $16 \%$ & $8 \%$ \\
\hline
\end{tabular}

Table 9 Other Enrollement Detailes

\begin{tabular}{|l|l|l|l|l|l|}
\hline Question & Yes & No & Question & Yes & No \\
\hline $\begin{array}{l}\text { Did you take the extra } \\
\text { course? }\end{array}$ & $41 \%$ & $59 \%$ & $\begin{array}{l}\text { Have you benefited from the } \\
\text { extra course? }\end{array}$ & $83 \%$ & $17 \%$ \\
\hline $\begin{array}{l}\text { Did you take the practice } \\
\text { course? }\end{array}$ & $65 \%$ & $35 \%$ & $\begin{array}{l}\text { Have you benefited from the } \\
\text { practice course? }\end{array}$ & $85 \%$ & $15 \%$ \\
\hline $\begin{array}{l}\text { Did you take the English } \\
\text { language course? }\end{array}$ & $91 \%$ & $9 \%$ & $\begin{array}{l}\text { Have you benefited from the } \\
\text { English language course? }\end{array}$ & $89 \%$ & $11 \%$ \\
\hline $\begin{array}{l}\text { Did you enter the electronic } \\
\text { library? }\end{array}$ & $53 \%$ & $47 \%$ & $\begin{array}{l}\text { Have you benefited from the } \\
\text { electronic library? }\end{array}$ & $72 \%$ & $28 \%$ \\
\hline
\end{tabular}

Table 10 Additional Questionnarie

\begin{tabular}{|l|l|l|}
\hline \multicolumn{1}{|c|}{ Question } & Yes & No \\
\hline Did you have a certificate for you enrolment in the platform? & $74 \%$ & $26 \%$ \\
\hline Did you complete the entire course? & $68 \%$ & $32 \%$ \\
\hline Did you drop the course? & $21 \%$ & $79 \%$ \\
\hline How broadly do you benefit from the platform? & $83 \%$ & $17 \%$ \\
\hline
\end{tabular}

D. Fourth Phase

In this phase and after we collect the data from the first and the second questionaries' Collecting dataset to be used in the MLP algorithm must be taken place, Four kinds of dataset have been collected to train and to test the proposed algorithm in the next step, this figure shows how data is collected as the following:

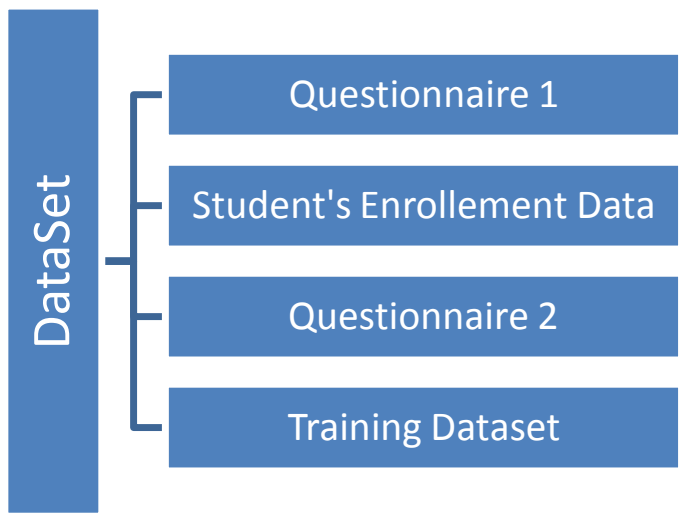

Fig. 9 Dataset Collection

E. $\quad$ Fifth Phase

In this Phase MLP algorithm is now ready to be used. Several factors affect the educational achievement of the learners. The research pattern is essentially directed on examining the prediction efficiency of the educational achievement of the learners utilizing uniquely affecting factors with Multi-Layer Perceptron algorithm, utilizing a dataset that includes of all educational and individual factors of the learners, these data is then fitted into a distinct table in order to be scanned by the proposed algorithm. Student profiling is necessary to the progress of 'one course fits all students' during our technological era computer based-learning is transformed into more intelligently educational methods that is suitable for each student. This flowchart shows the MLP-ANN flow as the following: 


\section{International Advanced Research Journal in Science, Engineering and Technology}

Vol. 6, Issue 5, May 2019

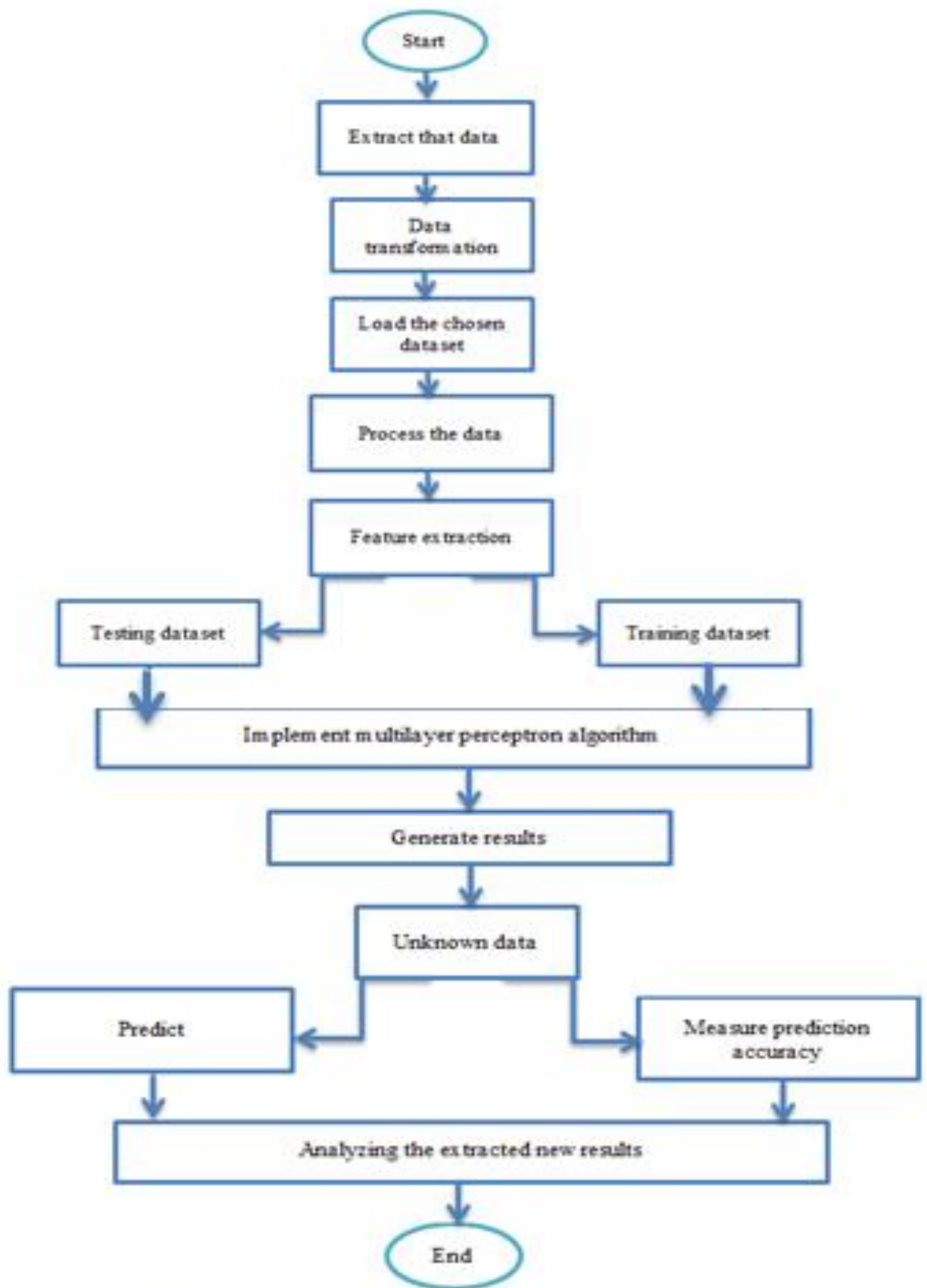

Flowchart 2 MLP flow

\section{Algorithm 2 Proposed MLP}

Step 1: Student's dataset is scanned.

Step 2: Define the values [m, $\mathrm{n}$, and $\mathrm{p}]$

Where: $\mathrm{m}$ is for training dataset, $\mathrm{n}$ is for testing dataset, and $\mathrm{p}$ is for testing the accuracy of the classifier

Step 3: Calculate the weight of each inserted attribute value.

Step 4: Apply the proposed algorithm.

Step 5: Evaluate the predicted results. 


\section{International Advanced Research Journal in Science, Engineering and Technology}

Vol. 6, Issue 5, May 2019

\section{EXPERIMENTS AND RESULTS}

A. Software Used

The software that is used to train and test MLP algorithm is called WEKA (Waikato Environment for Knowledge Analysis) is a common scale of machine learning software recorded in Java following GNU General Public License, formed at the University of Waikato, New Zealand. The Weka workbench includes a number of visualization accessories and algorithms for information analysis and predictive modelling, mutually with graphical user interfaces for clear access to this functionality.

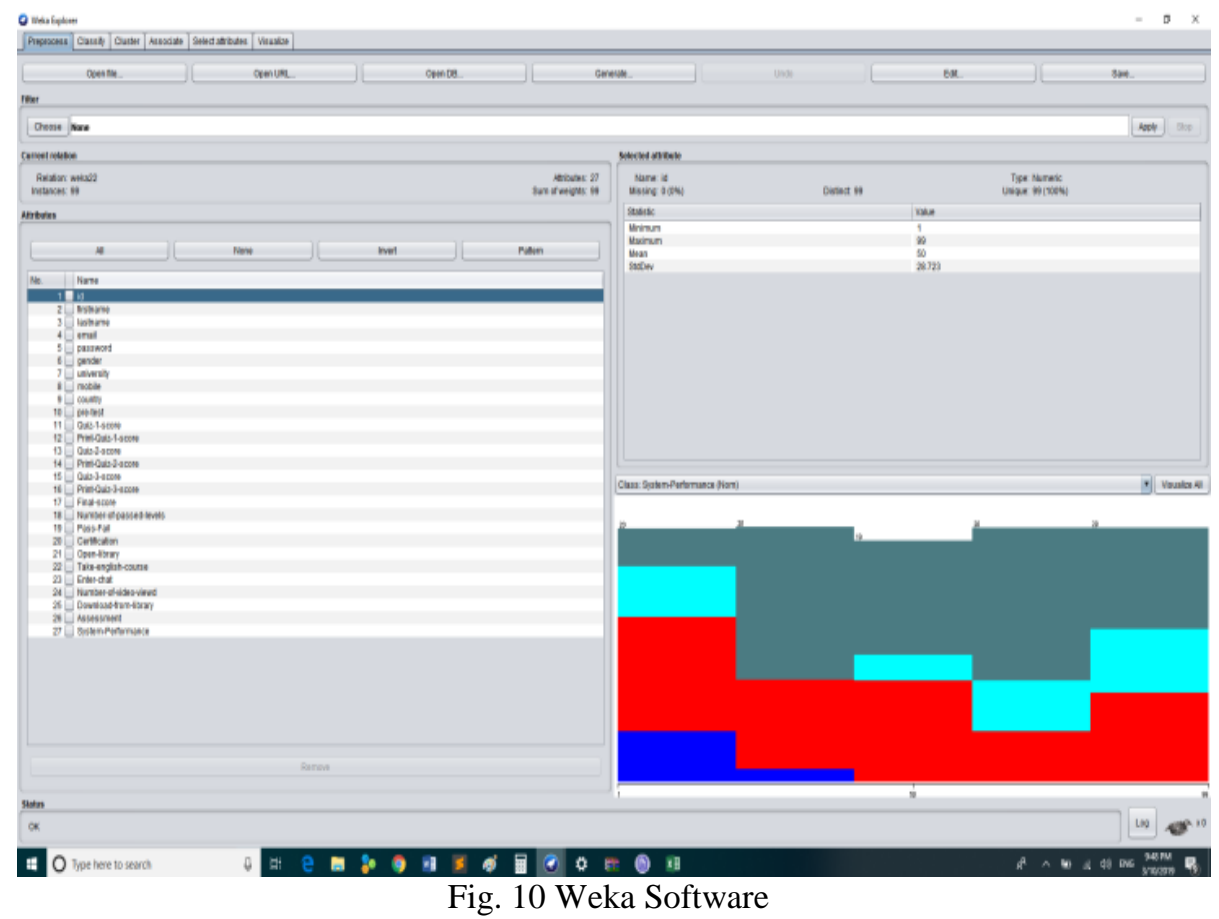

B. Results

First: Training dataset (MLP accuracy). In this model we divide the collected data into $75 \%$ of the collected students' data (demographic, learning behaviour, and grades) to train the prediction accuracy of the algorithm, the results shows that the correctly classified data according to system performance field (which is the field that is chosen to be predicted) is approximately $35 \%$, and the incorrectly classified dataset according to the same field is approximately $64 \%$, time taken to build the model is 0.01 second. Figurer below shows the results on GUI of WEKA software.

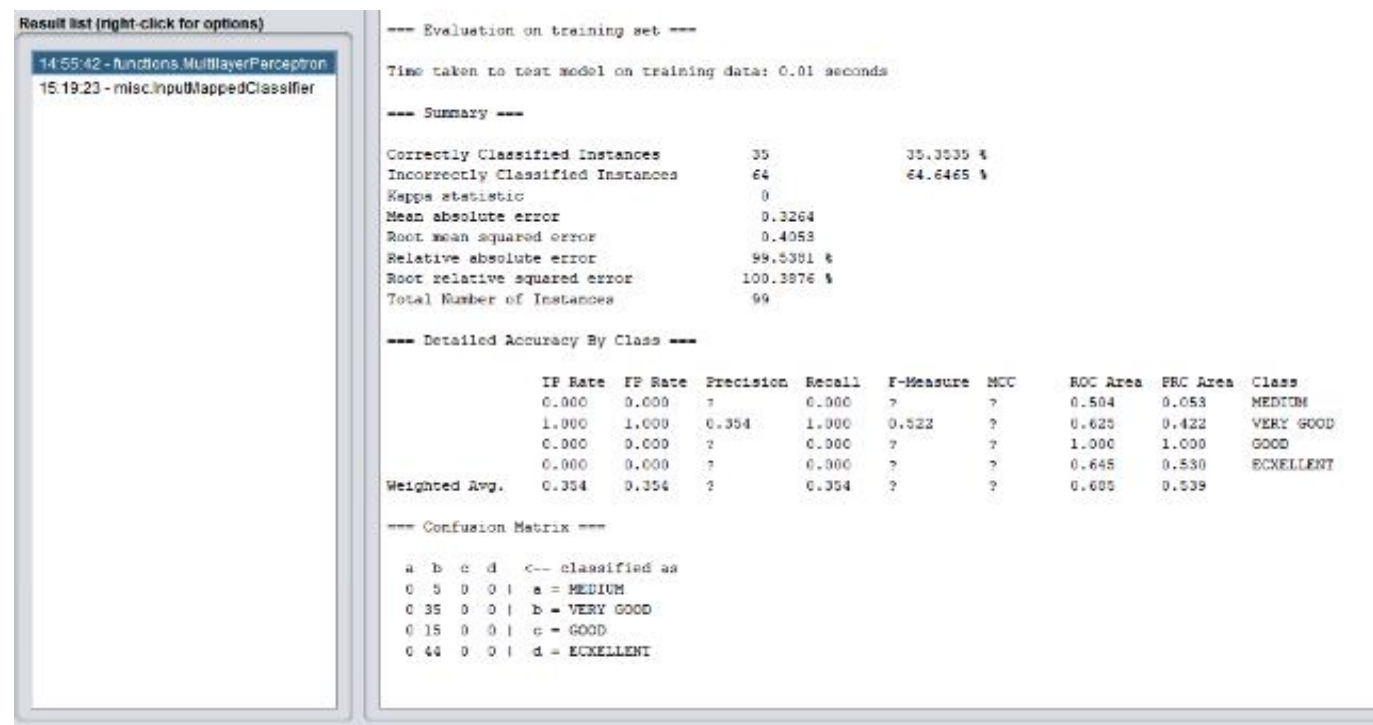

Fig. 11 Training Dataset 


\section{International Advanced Research Journal in Science, Engineering and Technology}

Vol. 6, Issue 5, May 2019

Second: Testing data set (MLP accuracy). In this model we use 25\% of the collected students' data (demographic data, learning style, and grades) for testing the prediction accuracy of the classifier, system performance field was also chosen to build a prediction according to its values, correctly classified data was about 55\%, incorrectly classified data was about $44 \%$, and the time taken to build the model is 0.03 seconds. Figurer below illustrates the obtained results.

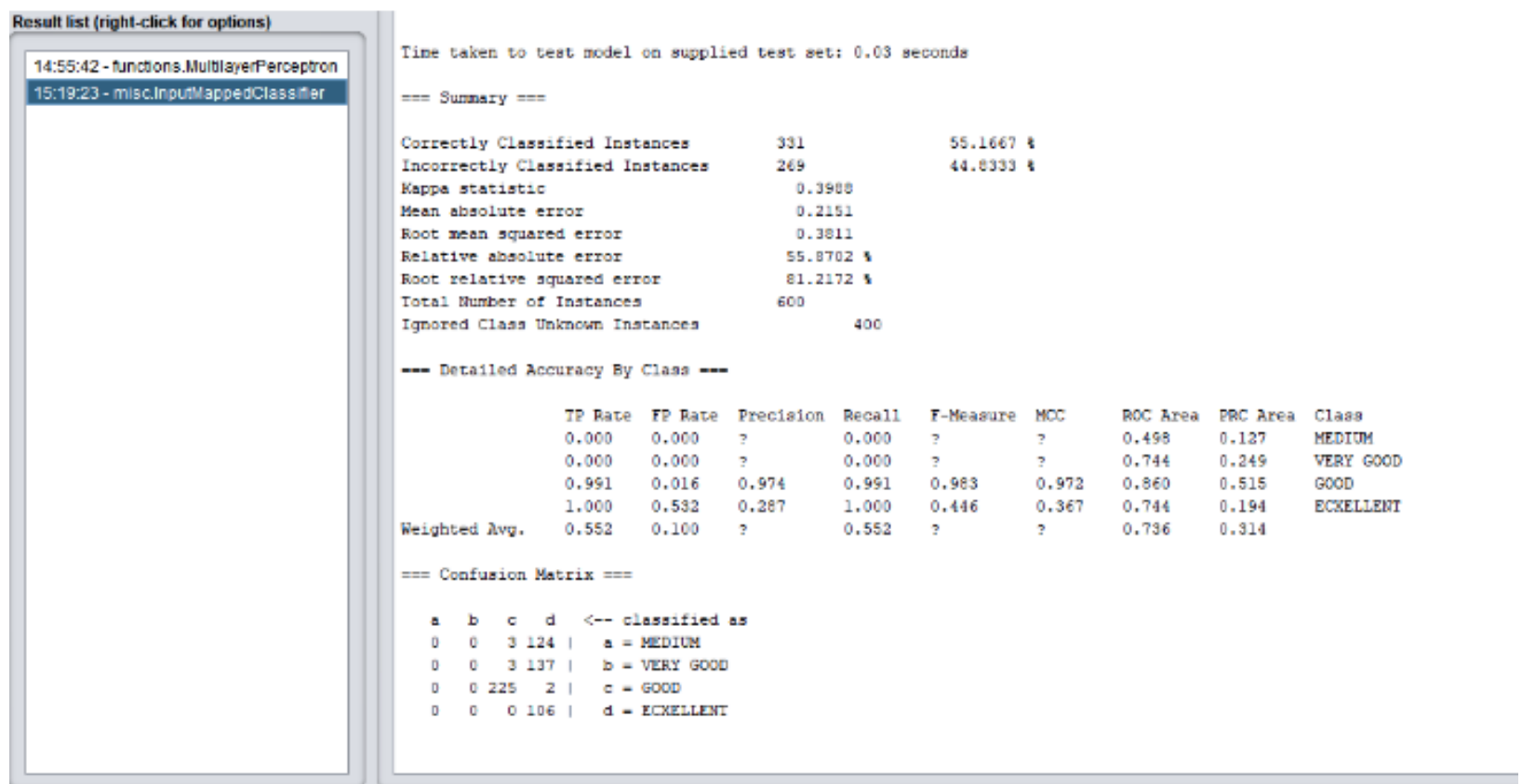

Fig. 12 Testing Dataset

Final obtained results between training and testing dataset of MLP algorithm shows that after the model has learned from previously known data, it was then tested after hiding the known data in order to extract knowledge and to predict the unknown values.

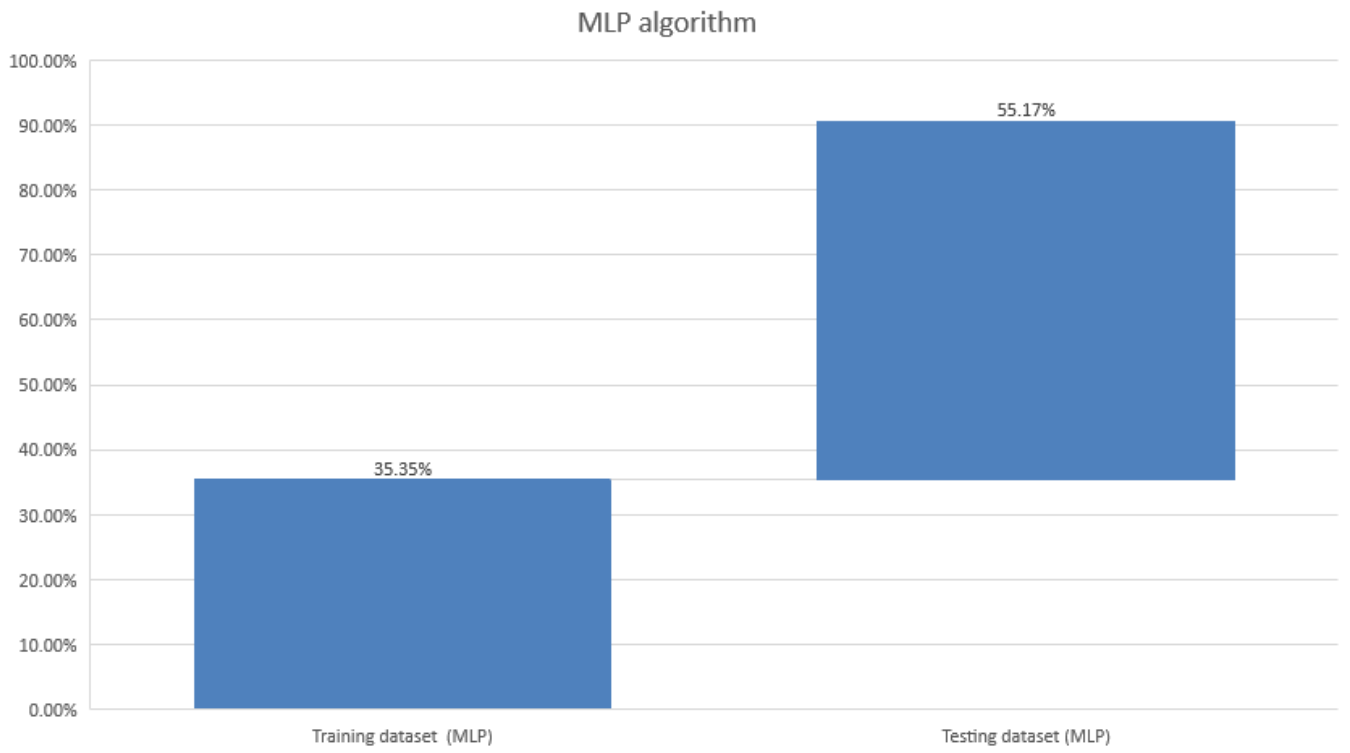

Fig. 13 Obtained Results

In addition to measure the accuracy of MLP algorithm prediction, in this paper we are also want to know the most influencing input data values in each student's record the results show that from 21 columns in the database only 12 columns considers the most influenced columns in each student's course as well as the overall platform performance measure. The table below shows the most influenced columns in the platform database. 


\section{International Advanced Research Journal in Science, Engineering and Technology}

Vol. 6, Issue 5, May 2019

Table 11 Influencing Factors

\begin{tabular}{|c|c|}
\hline Influencing Factor & Details \\
\hline Pre-test & $\begin{array}{l}77 \% \text { of the students who pass the pre-test form the third time and above and } \\
\text { considered it difficult are more likely to drop the course, while } 33 \% \text { of the users } \\
\text { who pass the pre-test from the first or second time and find it easy or medium are } \\
\text { more likely to complete the course to the end. }\end{array}$ \\
\hline Level-1-quiz & $\begin{array}{l}56 \% \text { of the students who pass the test from the second or third time and find it } \\
\text { difficult are more likely to drop the course, while } 44 \% \text { from them who find it } \\
\text { easy to medium and pass from the first try are more likely to complete the course. }\end{array}$ \\
\hline Level-2-quiz & $\begin{array}{l}49 \% \text { of the students who pass the test from the third time and find it difficult are } \\
\text { more likely to drop the course; on the other hand, } 51 \% \text { of the students who pass } \\
\text { the test from the first or the second time and find it easy to difficult are more } \\
\text { likely to complete the course. }\end{array}$ \\
\hline Level-2-final-quiz & $\begin{array}{l}63 \% \text { of the students who pass the test from the second or from the third time and } \\
\text { find it difficult are more likely to drop the course. While } 37 \% \text { of the students who } \\
\text { pass the test from the first or the second time and find it easy to difficult are more } \\
\text { likely to complete the course. }\end{array}$ \\
\hline Final score & $\begin{array}{l}\text { The final score varies from student to student and it is calculated according to the } \\
\text { formula (Pre-test score +quiz } 1 \text { score+quiz } 2 \text { score+quiz } 3 \text { score) } / 4\end{array}$ \\
\hline Pass or fail & $\begin{array}{l}61 \% \text { of the students don't have a final score because they drop the course so they } \\
\text { fail, while } 39 \% \text { have a very promising score and they pass the course }\end{array}$ \\
\hline Certification & $\begin{array}{l}55 \% \text { of the students who pass the course take a certification upon the completion } \\
\text { of the course while the others didn't have the desire to take the certification }\end{array}$ \\
\hline Electronic-library & $\begin{array}{l}\text { Approximately } 73 \% \text { of the students have downloaded and viewed the electronic } \\
\text { books inside the electronic library, while the rest of them didn't pay attention to } \\
\text { the additional material inside the library }\end{array}$ \\
\hline $\begin{array}{l}\text { Take-English- } \\
\text { course }\end{array}$ & $\begin{array}{l}96 \% \text { of the students took the English language course, while } 4 \% \text { only left it, and } \\
\text { this is a confirmation of how important this course can be }\end{array}$ \\
\hline Take-extra course & $\begin{array}{l}\text { Around } 43 \% \text { of the student who needed to re-take a certain course or an exam has } \\
\text { taken the extra course, while } 57 \% \text { didn't need it at all }\end{array}$ \\
\hline $\begin{array}{l}\text { Take practice- } \\
\text { course }\end{array}$ & $\begin{array}{l}\text { The high percentage of the students who re-take the course or an exam from the } \\
\text { second time have taken the practice course to help them, then return to complete } \\
\text { the rest of the course }\end{array}$ \\
\hline System Evaluation & $\begin{array}{l}\text { Electronic system evaluation is the most important evaluation because it takes all } \\
\text { the above data and analysis it to produce a final result that can help the } \\
\text { supervisors and teachers to enhance the performance of the platform. In this case, } \\
\text { system evaluation gives the result of } 49 \% \text { good result, and } 51 \% \text { of the bad result. }\end{array}$ \\
\hline
\end{tabular}

\section{CONCLUSION AND FUTURE WORK}

This research casts the light on barriers imposed on academic members and undergraduate students in public Iraqi universities when it comes to using e-learning technology in teaching and learning. Also, this research put forward several views on how to reduce the delay of Iraqi universities in the application of e-learning. Two types of questionnaire were taken place to accumulate data from the institution, upon the results we designed and implemented an intelligent e-learning platform that can observe the learning style of each student to study the most influenced factors to evaluate the performance of the proposed e-learning platform that has been designed for higher education studies based on a previously collected student's dataset. Synthetic data of three educational years with 1000 row each have been generated to train the model, as well as 100 real students, use the proposed platform to observe their learning style, $75 \%$ of the data have been utilized for that purpose, and $25 \%$ kept to be used later to test the accuracy of the propped algorithm. A 10 folds cross-validation have been generated, and WEKA software is used to train and test the algorithm, the obtained results from training dataset were 35\%, and the results after testing the MLP model were 55\% which is a promising result. This research shows the characteristics extracted from the dataset are very high influence by utilizing MLP. This paper supports the institutions to better understand the educational situation of each learner in 


\title{
International Advanced Research Journal in Science, Engineering and Technology
}

\author{
Vol. 6, Issue 5, May 2019
}

the future and they can focus the student's with weak performance to strength their weakness later and develop their academic achievement. In future work, we suggest observing more of the student's learning behaviour. For instance, cheating detection, whether the student is gaming the system or take it seriously, more features can be added to the platform to extract new hidden knowledge would be great, then we suggest to use other artificial intelligence tools or merging two or more new algorithms for more accurate prediction or a different algorithm can be extended for larger classification and prediction utilizing the important influence extracted by EDM.

\section{REFERENCES}

[1]. N. V. K. Rao, N. Mangathayaru, and M. S. Rao, "Evolution and prediction of radical multi-dimensional e-learning system with cluster based data mining techniques," in 2017 International Conference on Trends in Electronics and Informatics (ICEI), 2017, pp. 701-707.

[2]. V. Sarala, Dr. v.v. Jaya Rama krishnaiah, "empirical study of data mining techniques in education system", international journal of advances in computer science and technology (ijacst), vol. 4 no.1, pages: $15-212015$

[3]. Jasvinder Kumar, a Comprehensive Study of Educational Data Mining, International Journal of Electrical Electronics \& Computer Science Engineering Special Issue - TeLMISR 2015, ISSN: 2348-2273.

[4]. Jai Ruby \& K. David,“Analysis of Influencing Factors in Predicting Students Performance Using MLP - A Comparative Study “, International Journal of Innovative Research in Computer and Communication Engineering, Vol. 3, Issue 2, February 2015.

[5]. Jai Ruby \& K. David, "Predicting the Performance of Students in Higher Education Using Data Mining Classification Algorithms - A Case Study“, IJRASET International Journal for Research in Applied Science \& Engineering Technology, Volume 2 Issue XI, November 2014

[6]. A.F.ElGamal, "An Educational Data Mining Model for Predicting Student Performance in Programming Course", International Journal of Computer Applications (0975 - 8887) Volume 70- No.17, May 2013

[7]. Thilina Ranbaduge, "Use of Data Mining Methodologies in Evaluating Educational Data", International Journal of Scientific and Research Publications, ISSN 2250-3153, Volume 3, Issue 11, November 2013

[8]. Annabel Latham, Keeley Crockett, David Mclean The Intelligent Systems Group, School of Computing, Mathematics and Digital Technolog "Profiling Student Learning Styles with Multilayer Perceptron Neural Networks", The Manchester Metropolitan University 2013

[9]. T. Chellatamilan, M. Ravichandran, R. M. Suresh, and G. Kulanthaivel, "Effect of mining educational data to improve adaptation of learning in e-learning system," in International Conference on Sustainable Energy and Intelligent Systems (SEISCON 2011), 2011, pp. 922-927.

[10]. Wilton W.T. Fok; Y.S. He; H.H. Au Yeung; K.Y. Law ; KH Cheung; YY. Ai ; P. Ho, "Prediction model for students' future development by deep learning and tensorflow artificial intelligence engine - IEEE Conference Publication", International Conference on Information Management (ICIM-2018)

[11]. Anoopkumar M ; A. M. J. Md. Zubair Rahman, "A Review on Data Mining techniques and factors used in Educational Data Mining to predict student amelioration - IEEE Conference Publication," International Conference on Data Mining and Advanced Computing (SAPIENCE-2016)

[12]. JR K David "An Analysis on Academic Performance of Students using a Hybrid Model for Higher Education", International Journal of Engineering and Technology (IJET) 9 (3), 2175-2182 (2017)

[13]. S. Q. Wei Zhang, "A brief analysis of the key technologies and applications of educational data mining on online learning platform," IEEE International Conference on Big Data Analysis (ICBDA-2018) 